\title{
Landform classification for digital soil mapping in the Chongwe-Rufunsa area, Zambia
}

\author{
Lydia Mumbi Chabala ${ }^{1}$, Augustine Mulolwa ${ }^{2}$, Obed Lungu ${ }^{1}$ \\ ${ }^{1}$ Department of Soil Science, University of Zambia, School of Agricultural Sciences, P.O. Box 32379, Lusaka, Zambia \\ ${ }^{2}$ Department of Geomatic Engineering, University of Zambia, School of Engineering, National Remote Sensing Center, Lusaka, Zambia
}

\section{Email address:}

lchabala@unza.zm (L. M. Chabala),amulolwa@gmail.com (A. Mulolwa),olungu@unza.zm (O. Lungu)

\section{To cite this article:}

Lydia Mumbi Chabala, Augustine Mulolwa, Obed Lungu. Landform Classification for Digital Soil Mapping in the Chongwe-Rufunsa Area, Zambia. Agriculture, Forestry and Fisheries. Vol. 2, No. 4, 2013, pp. 156-160. doi: 10.11648/j.aff.20130204.11

\begin{abstract}
This paper presents results of a landform classification of a section of the Chongwe-Rufunsa area, Zambia. The objective of the study was to separate the landscape into landform classes that indicate or suggest marked differences with respect to soil properties and agricultural suitability. Terrain attributes derived from a digital elevation model were overlaid using cell statistics to generate a landform map with five classes. The generated landform map had an overall classification accuracy of $73.51 \%$. The landform map provided a base for benchmark soil sampling for ongoing research on digital soil mapping.
\end{abstract}

Keywords: Landform, Digital Elevation Model, Terrain Attribute

\section{Introduction}

Landforms can be understood as geomorphologic units described by their surface form and location in the landscape [2]. The study and classification of landforms lends itself to the fields of hydrology, forestry and pedology (soil science) among others.

In pedology, landforms can be used to obtain a general impression of soil-forming processes and implicitly soil properties. Thus, the soil catena concept is inherently a reflection of landform classes. The soil catena concept theorizes that soil occurrence is a function of topography. Therefore, a key step to understanding the soil occurrence pattern is to separate the landscape into meaningful landform classes. In traditional soil mapping approaches, this is achieved by the field conceptual model of the soil surveyor's impression of the landscape. Thus traverses and sampling points are located according to perceived landforms in the landscape under consideration or from delineations on aerial photographs. In digital soil mapping, this can be achieved by classifying the existing digital elevation models (DEM). This approach uses automated methods, is consistent and thus easier to update than traditional methods. Although several methods of landform classification have been applied, the absence of standards [9] means that for any given location, the method to be applied has to be adapted according to the local environment.
This paper presents results of a land form classification of a section of the Chongwe-Rufunsa area in Zambia, as part of the inputs being used in the mapping of soils using pedometric mapping approaches. The motivation of the study was to adapt the Zambian Land Capability Classification System [14] in the extraction of terrain attributes used in landform segmentation. The objective of the study was to separate the landscape into landform classes that indicate or suggest marked differences with respect to soil properties.

\section{Materials and Methods}

\subsection{Study Site}

The study site is located in the Chongwe-Rufunsa area in Lusaka Province of Zambia (Figure 1). It is located at longitudes $28^{\circ} 45^{\prime \prime} \mathrm{E}$ and $29^{\circ} \mathrm{E}$ and latitudes $15^{\circ} 07^{\prime \prime} \mathrm{S}$ and $15^{\circ} 20^{\prime \prime} \mathrm{S}$ and covers parts of Munyeta and Mwapula local forest. It has an estimated area of 634 square kilometers. The geographic relief of the area is characterized by dambos, rivers and a plane plateau. It has a distinct range of prominent hills known as the Chainama Hills transcending through the study site. The elevations range from 970 to 1420 meters above sea level. The area is underlain by varying rock types with the major ones being pyrrhorite, ilmenite, sugary quartzite and biotite granites $[7,11]$. The average annual rainfall is between $700-1000 \mathrm{~mm}$. 


\subsection{Data Sources}

The void-filled $90 \mathrm{~m}$ resolution DEM (Figure 1) produced by the NASA Shuttle Radar Topographic Mission (SRTM) was downloaded from http://earthexplorer.usgs.gov. This data set was selected as it would fittingly represent the conceptual understanding of the soil catena concept. Further work is being done with a $20 \mathrm{~m}$ resolution local DEM generated after extraction of contours from a 1:50,000 topographic map. It is worth noting, however, that DEMs interpolated from contour data often display bias towards elevations of contours data because of the high density of data along contours compared to no data areas which gives a more variation in shape (curvature)where data are densest [13]. Just how this will be true for the study area is yet to be seen as the landform classification using the contour created DEM is currently underway.

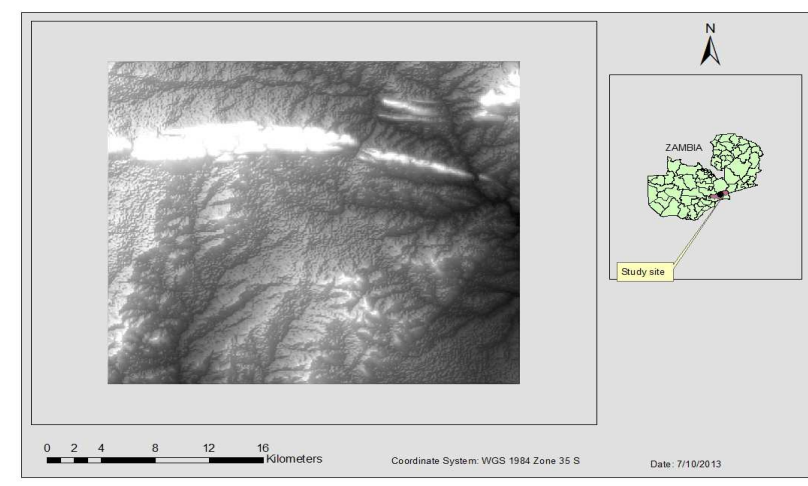

Figure 1: Location of study site with a snap shot of the DEM for the study area

\subsection{Pre-Processing of the DEM}

The DEM was projected to UTM coordinates in WGS 84 Zone 35 South. Pre-processing of the DEM was done to remove sinks (small imperfections in the data) and this was implemented in ArcGIS 10.1. A flow direction data set was first generated from the DEM to which the sink tool was applied to obtain a data set of 'sinks'. The 'sinks' data set was further processed with the watershed tool to obtain 'sink areas'. Zonal statistics was then applied to 'sink areas' with the DEM being the input raster value and the statistic type set at the minimum to generate a raster of 'minimum sinks'. Further, the zonal fill tool was applied to 'sink areas' with DEM used as the weight raster to obtain a data set of 'maximum sinks'.

The minus tool was used to subtract the 'minimum sinks' from the 'maximum sinks' to generate the 'sink depth' which was 8 . The fill tool was then applied to the elevation grid (DEM) with a $\mathrm{Z}$ limit set at 8 to generate a DEM with all sinks filled. This final sink-filled DEM was referred to as the 'corrected DEM'. A low pass filter was applied to the 'corrected DEM' to smoothen any anamolus cells [5]. This was the DEM that was used in the extraction of covariates for land form classification.

\subsection{Selection of Covariates for Landform Classification}

The term covariate in the context of landform classification refers to terrain attributes of the landscape. These attributes can be combined in order to derive the landform classes. The terrain attributes were selected following a preliminary visit to the area which indicated that topography was one of the dominant factors of soil formation at the site. The selected covariates were slope, elevation, relief intensity, and curvature. The processing steps for the extraction of terrain attributes are summarized in the process model shown in figure 2. The following sections describe procedures employed in the extraction of terrain attributes and generation of the landform map which was implemented in ArcGIS 10.1(ArcInfo software).

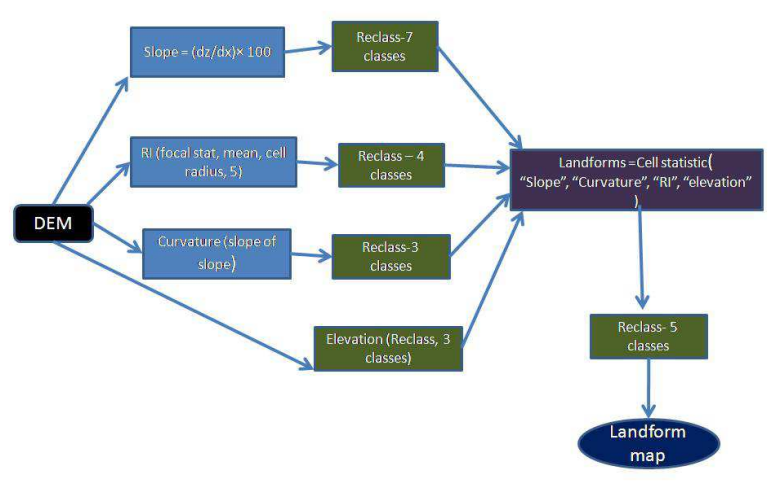

Figure 2: Process model for extraction of terrain attributes and landform classification

\subsubsection{Slope}

Slope is a fundamental aspect of the landscape and serves as a major input in landform classification which has been applied in a number of studies $[1,4,6,8$, and 10]. It is a measure that denotes the change in steepness or inclination of a given surface over the horizontal plane. Slope can be expressed in degrees or percent. Slope in degrees is obtained by calculating the arctangent of the ratio of the change in height $(\mathrm{dz})$ to the change in horizontal distance $(\mathrm{dx})$ while percent slope is equal to the change in height(dz) divided by the change in horizontal distance $(\mathrm{dx})$ multiplied by 100 [5]. It can be expressed:

Slope $($ degree $)=\arctan (\mathrm{dz} / \mathrm{dx})$

Slope $($ percent $)=(\mathrm{dz} / \mathrm{dx}) * 100$

Slope was extracted using the slope tool in ArcInfo. This tool calculated slope based on the average maximum technique [3] operating on a 3 by 3 matrix of eight neighboring cells. The extracted slope image was then reclassified into seven classes (Table 1 and Figure 4). Slope classes were adapted from the Zambian Land Capability Classification (LCC) [14] and the Soil Terrain digital database (SOTER) procedures as described by Dobos et al. [4]. Since the Zambian LCC had only 6 classes, the last class in the LCC with slope $>12 \%$ was merged with the SOTER 
classes.

Table 1: Slope classes

\begin{tabular}{ll}
\hline Slope class & Percentage range of slope \\
\hline 1 & $0-1.00$ \\
2 & $1.01-3.00$ \\
3 & $3.01-5.00$ \\
4 & $5.01-8.00$ \\
5 & $8.01-12.00$ \\
6 & $12.01-30.00$ \\
7 & $30.01-45.00$ \\
\hline
\end{tabular}

\subsubsection{Elevation}

The elevation was reclassified from the 'corrected DEM' into 3 classes (Table 2 and Figure 3 ). The classes represented nearly level land, sloping land and steep sloping land. The reclassification was based on field observation made during the preliminary field visit.

Table 2: Elevation classes

\begin{tabular}{llc}
\hline Class & Description & Elevation range (m) \\
\hline 1 & nearly level land & $976.33-1080.00$ \\
2 & Sloping land & $1080.01-1180.00$ \\
3 & Steep sloping land & $1180.01-1420.00$ \\
\hline
\end{tabular}

\subsubsection{Relief Intensity}

Relief intensity refers to changes in elevation between the lowest and highest points over a given section of the landscape. The procedure for the extraction of relief intensity was based on the algorithm described by Dobos et al. [4] and was implemented using the focal statistics tool in ArcInfo. The focal statistics tool calculated the average value for each input cell location in a circular neighbourhood with a radius of 5 cells. The five cells for a 90 m resolution DEM represented $990 \mathrm{~m}$ which was a close approximation to the unit used for relief intensity ( $\mathrm{m} /[$ area of a $1 \mathrm{~km}$ diameter circle] in the SOTER procedures. The generated image was then classified into four classes of relief intensity as shown in Table 3 and Figure 3.

Table 3: Relief Intensity (RI) Classes

\begin{tabular}{ll}
\hline RI Class & $\begin{array}{l}\text { Altitude range within a } 990 \mathbf{~ m} \\
\text { diameter circle }\end{array}$ \\
\hline 1 & $976-1030$ \\
2 & $1031-1100$ \\
3 & $1101-1180$ \\
4 & $>1180$ \\
\hline
\end{tabular}

\subsubsection{Curvature}

Curvature can be described as curves of a surface formed when it intersects with a surface plane of specific orientation and can be represented as profile, plan or general curvature [12]. In this study, general curvature was used. General curvature is the curvature of the surface itself and is the second derivative of $\mathrm{Z}$ (elevation) with respect to $\mathrm{S}$ (aspect) or the slope of the slope. It can be convex, concave or zero. According to Wilson and Gallant [13] the general curvature (K) can be expressed:

$$
K=Z_{x x}^{2}+2 z_{x y}^{2}+z_{y}^{2}
$$

The curvature was calculated with the curvature tool in ArcInfo. The tool calculated the second derivative value of the elevation grid (corrected DEM) on a cell-by-cell basis. For each cell, a fourth-order polynomial of the form:

$$
\mathrm{Z}=\mathrm{Ax}^{2} \mathrm{y}^{2}+\mathrm{Bx}^{2} \mathrm{y}+\mathrm{Cxy}^{2}+\mathrm{Dx}^{2}+\mathrm{Ey}^{2}+\mathrm{Fxy}+\mathrm{Gx}+\mathrm{Hy}+\mathrm{I}
$$

was fitted to a surface composed of a $3 \times 3$ window [5]. The coefficients A -I were calculated from this surface. The output image of curvature was then classified into three classes to represent peaks, depressions and linear surfaces as shown in Table 4 and Figure 4.

Table 4: Curvature classes

\begin{tabular}{lll}
\hline Class & $\begin{array}{l}\text { Description of } \\
\text { surface and shape }\end{array}$ & $\begin{array}{c}\text { Range (1/100 of } \\
\text { elevation in m) }\end{array}$ \\
\hline 1 & $\begin{array}{l}\text { Depressions } \\
\text { (concave) }\end{array}$ & $-0.332-0.095$ \\
2 & Flat surfaces & $>0.095-0.140$ \\
3 & Peaks and ridges & $>0.140-0.379$ \\
\hline
\end{tabular}
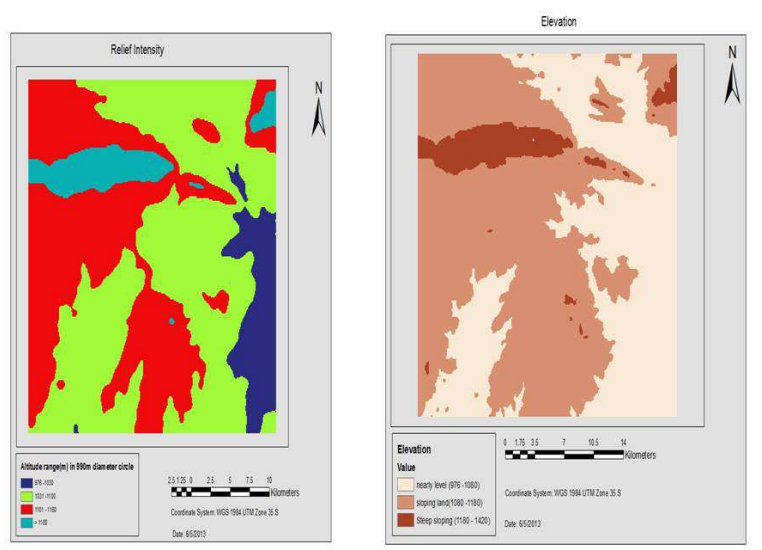

Figure 3: Extracted and reclassified covariates of Relief intensity and Elevation 

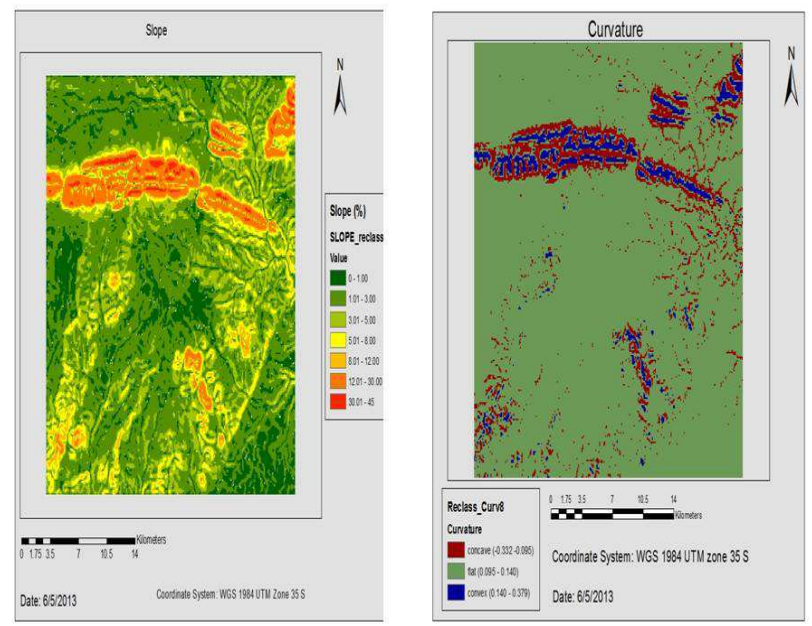

Figure 4: Extracted and reclassified covariates of slope and curvature

\subsection{Landform Generation}

The landform map was generated by overlaying the reclassified grids representing relief intensity, curvature, elevation and slope. This was done using the cell statistics tool in ArcInfo with the mean set as the overlay statistic. The expression for the operation is given as:

\section{Landforms = CellStatistics(["Slope", "Curvature", "Elevation", "Relief Intensity"] )}

The output from the cell statistic tool was a continuous grid which was classified into five landform classes (Table 5 and Figure 5). Ground truthing was undertaken in accessible parts of the study area by the principal author and a field technician from the Ministry of Agriculture and Livestock. A total of 151 locations were visited with GPS points taken and accompanying landform type and elevation noted. A classification assessment was done by comparing the landforms on the classified map with the actual landform observed in the field.

\section{Results and Discussion}

The landform map for the study area is presented in Figure 5. It was observed that landscapes classified as lowlands (toe slope) represented low gradient, plateau areas that may be characterized by open woodlands to open wooded grasslands. Their slopes ranged from more than 1 up to $3 \%$ with generally flat curvatures and an elevation range of $976-1180 \mathrm{~m}$. The landscapes classified as dambos (foot slope) were surfaces at lowest elevation in the area where the water table usually rises above the ground for a considerable part of the year and comprises mainly of grassland vegetation. These landscapes had slopes of less than $1 \%$ with a concave to flat curvatures and an elevation range of $976-1080 \mathrm{~m}$ and relief intensity in the range $976-1030 \mathrm{~m}$.

The landscapes classified as plateaus (back slope) represented upland areas with flat surfaces normally used for dryland farming. The slopes ranged from more than $3-8 \%$, with generally flat curvatures an elevation and relief intensity in the range of $1030-1180 \mathrm{~m}$.

The landscapes classified as the upper terraces or shoulder represented areas adjacent to hill tops with a medium to strong dissection and had slopes of more than 8 up to $12 \%$ with concave curvatures. Their elevation was more than $1180 \mathrm{~m}$ and relief intensity in the range $1100-1180 \mathrm{~m}$. The landscapes classified as hilltops or summit were upland land surfaces with convex surfaces characteristics and slopes of more than $12 \%$. Their elevation was more than $1180 \mathrm{~m}$ and relief intensity in the range 1180 to $1375 \mathrm{~m}$.

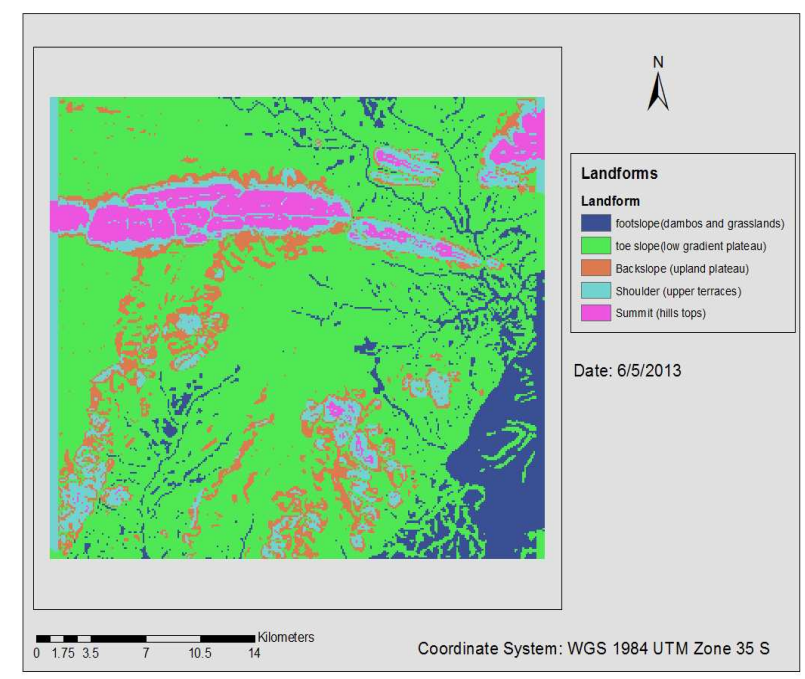

Figure 5: Landform map of the study area

\subsection{Accuracy of the Landform Map}

The landform map was qualitatively matched with a topographic map at a scale of 1:50, 000. Qualitatively, a good agreement was observed between the topographic map and the generated landform map. Compared to ground truth data, the overall classification accuracy of the land form map was $73.51 \%$ (Table 5) which was better than the accuracy of traditional methods whose accuracy is in the range of 50 $-55 \%$ [10]. It was observed that the landforms classified as lowlands and plateau had the highest accuracy at $86.18 \%$ and $71.19 \%$ respectively. The dambos were $68.18 \%$ accurate for the sites visited while the upper terraces were at $57.14 \%$ for the sites visited. The hills had the lowest level of accuracy at $25 \%$. Ironically the hills also had the fewest sites visited owing to difficulty with accessibility to the sites. It was also noted that in some cases the landforms classified as lowlands (low gradient plateau) were misclassified into plateau (upland plateau) or dambos and grasslands. This is not surprising, as the curvature for both plateau and lowland is flat and there was an overlap in the elevation and relief intensity range between the two classes. Further, the lowlands are an intermediate landscape that may characterize back slopes or foot slopes when conceptualized from the soil catena model. 
Table 5: Accuracy of landform map

\begin{tabular}{llll}
\hline Landforms & $\begin{array}{l}\text { Number of } \\
\text { sites } \\
\text { (\#sites) }\end{array}$ & $\begin{array}{l}\text { Number of } \\
\text { correctly } \\
\text { classified } \\
\text { landforms } \\
\text { (CCLF) at } \\
\text { visited sites }\end{array}$ & $\begin{array}{l}\text { Percentage of } \\
\text { correctly } \\
\text { classified } \\
\text { landforms } \\
\text { CCLF/\#sites } \\
* 100\end{array}$ \\
\hline Hills (summit) & 4 & 1 & 25.00 \\
$\begin{array}{l}\text { Upper terraces } \\
\text { (shoulder) }\end{array}$ & 14 & 8 & 57.14 \\
$\begin{array}{l}\text { Plateau(back } \\
\text { slope) }\end{array}$ & 59 & 42 & 71.19 \\
$\begin{array}{l}\text { Dambos (foot } \\
\text { slope) }\end{array}$ & 22 & 15 & 68.18 \\
$\begin{array}{l}\text { Lowlands (toe } \\
\text { slope) }\end{array}$ & 52 & 45 & 86.54 \\
\begin{tabular}{l} 
Total \\
\hline
\end{tabular} & 151 & 111 & 73.51 \\
\hline
\end{tabular}

\section{Conclusions}

This paper has presented part of the work on the research being undertaken on pedometric mapping in Chongwe-Rufunsa area. It is an automated and quantitative perspective to landform classification applied to the study site. The generated landform map showed an overall classification accuracy of $73.50 \%$. Since the SRTM developed DEM is freely available for the whole of Zambia, it is recommended that further testing of the applied methods be carried out in order to generate an updated national map of landforms in Zambia.

\section{Acknowledgements}

The authors acknowledge support of the University of Zambia and the National Remote Sensing Center, Zambia. Mr. Kethern Banda from Ministry of Agriculture and Mr Sandrum Sakala of University of Zambia are acknowledged for their immense contribution during field work. The study was conducted with partial financial support from the Ministry of Science and Technology, Zambia.

\section{References}

[1] Barka I., J. Vladovic and F. Malis. 2011. Landform classification and its application in predictive mapping of soil and forest units. GIS Ostrava, 1, 23-26. [Accessed 20 May 2013]. Available from: www.GIS.lsb.cz/GIS-ostrava/GIS_ova2011.

[2] Barker V.R. 2009. Introduction: Regional landform analysis. Avalaible online from Goddard Earth Sciences Data and Information Center. [Accessed 6 June 2013]. Available from: www.disc.sci.gsfc.nasa.gov/geomorphology/

[3] Burrough, P.A. and McDonnell R.A. 2004. Principles of Geographical Information Systems. Oxford University Press, New York, p. 190.

[4] Dobos, E., J. Daroussin and L. Montanarella.. 2005. An SRTM-based procedure to delineate SOTER Terrain Units on 1:1 and 1:5 million scales. EUR $21571 \mathrm{EN}, 55 \mathrm{pp}$. Office for Official Publications of the European Communities, Luxembourg.

[5] Environmental Systems Research Institute (ESRI). 2013. Cell Statistics (Spatial Analyst). Anonymous. [Accessed 25 March 2013]. Available from: http://resources.arcgis.com/en/help/main/10.1/index.ht $\mathrm{ml} \# / / 009 \mathrm{z} 0000007 \mathrm{q} 000000$

[6] Huting J.R.M., J. A. Dijkshoorn and V.W.P van Engelen. 2008. GIS procedures for mapping SOTERlandform for the LADA partner countries (Argentina, China, Cuba, Senegal and The Gambia, South Africa and Tunisia). ISRIC report 2008/04 and GLADA report 2008/02, ISRIC - World Soil Information and FAO, Wageningen (30 pp with data set). Available from: http://www.isric.org/isric/Webdocs/Docs/ISRIC_Repo rt_2008_04.pdf

[7] Garrard, P. 1968. The geology of the Chainama Hills area: Explanation of the degree sheet 1528, NE Quarter. Geological Survey of Zambia. Report No. 24.

[8] Iwahashi J. and R.J.Pike. 2006. Automated classifications of topography from DEMs by unsupervised nested-means algorithm and a three part geometric signature. Geomorphology 86, 409 - 440. [accessed 6 June 2013]. Available from: www.sciencedirect.com.

[9] MacMillan R. 2011. Automated extraction of land forms from DEM data. Workshop presentation. [Accessed 18 May 2013]. Available from: www.slideshare.net/bob_macmillan/automated-extract ion-of-landforms-from-dem-data-13062121

[10] Saadat H., Bonnell R., Sharifi F., Mehuys M. and Ale-Ebrahim S. 2008. Landform classification from digital elevation model and satellite imagery. Geomorphology 100, 453 -464.[Accessed 20 May 2013]. Available from: www.sciencedirect.com.

[11] Simpson, J.G. 1967. The geology of the Chinyunyu area: Explanation of the degree sheet 1529, NW Quarter. Geological Survey of Zambia. Report No. 19.

[12] Thorne, C.R, Zevenbergen L.W, Burt T.P. and Butcher D.P. 1987. Terrain analysis for quantitative description of zero order basins. Ersosion and Sedimentation in the Pacific Rim. Proceedings of the Corvallis Symposium, August, 1987.

[13] Wilson J.P and J. C. Gallant. 2000. Terrain Analysis: Principles and Applications. John Wiley and Sons, Inc. Chichester, Canada

[14] Woode P. 1988. Field guide for soil surveyors. Technical guide no. 18. Soil Survey Unit, Department of Agriculture, Zambia. 